\title{
Oxygen Concentrations in Tents and Incubators in Paediatric Practice
}

\author{
HAMISH SIMPSON,* M.B., M.R.C.P.ED., D.C.H. ; DOREEN J. RUSSELL, * S.R.C.N.
}

Brit. med. F., 1967, 4, 201-203

Oxygen therapy is a common requirement in paediatric practice and is generally administered in commercially available tents or incubators. Batson and Young (1958) stated that they were " unable to create and maintain therapeutic concentrations of oxygen in tents," and it is therefore surprising that alternative, more efficient, methods of administering oxygen (Burgess and Burgess, 1932 ; Morrison, 1955 ; Batson and Young, 1958 ; Godfrey, 1959) have not found wider acceptance.

Oxygen concentrations of at least $60 \%$ are claimed for many of their products by the manufacturers of tents and incubators, tested under laboratory conditions. As an inspired oxygen concentration of $40 \%$ does not invariably relieve hypoxia in infants with acute respiratory failure (Downes and Striker, 1966 ; Simpson and Flenley, 1967), it seems particularly relevant to report the oxygen concentrations attainable in present-day tents and incubators during clinical use.

\section{Tents and Incubators}

Six tents (Table I) and four models of incubator (Table II) were studied. Tents 1 (Air-Shields Type D Croupette), 2 (Air-

TABle I.-Oxygen Concentrations in Tents Under Ideal Clinical Conditions

\begin{tabular}{|c|c|c|c|c|c|c|c|}
\hline \multicolumn{2}{|r|}{ Oxygen Tent } & \multirow[t]{2}{*}{$\begin{array}{c}\text { No. of } \\
\text { Observa- } \\
\text { tions }\end{array}$} & \multirow{2}{*}{$\begin{array}{l}\text { Oxygen } \\
\text { Flow } \\
\text { Rate } \\
\text { (1./min.) }\end{array}$} & \multicolumn{2}{|c|}{$\begin{array}{c}\text { Actual } \\
\text { Concentration } \\
\text { at Child's } \\
\text { Mouth (\%) }\end{array}$} & \multirow{2}{*}{$\begin{array}{c}\text { Possible } \\
\text { Oxygen } \\
\text { Concen- } \\
\text { tration } \\
\text { Claimed } \\
(\%)\end{array}$} & \multirow[t]{2}{*}{ Notes } \\
\hline No. & Model & & & Range & Mean & & \\
\hline 1 & $\begin{array}{l}\text { Type D } \\
\text { Croupette } \\
\text { (Air-Shields, } \\
\text { Inc.) }\end{array}$ & 2 & $\begin{array}{r}2 \\
4 \\
6 \\
8 \\
10\end{array}$ & $\begin{array}{l}40-41 \\
40-44 \\
45-51 \\
50-52 \\
50-52\end{array}$ & $\begin{array}{l}40 \\
42 \\
48 \\
51 \\
51\end{array}$ & 60 & (a) \\
\hline 2 & $\begin{array}{l}\text { Universal } \\
\text { Croupette } \\
\text { (Air-Shields, } \\
\text { Inc.) }\end{array}$ & 4 & $\begin{array}{l}10 \\
20\end{array}$ & $\begin{array}{l}28-31 \\
28-35\end{array}$ & $\begin{array}{l}30 \\
30\end{array}$ & 65 & (b \\
\hline 3 & $\begin{array}{l}\text { Humidaire Tent } \\
\text { (Oxygenaire } \\
\text { Ltd.) }\end{array}$ & 2 & $\begin{array}{r}2 \\
4 \\
6 \\
8 \\
10 \\
20\end{array}$ & $\begin{array}{l}39-43 \\
45-48 \\
50-55 \\
56-60 \\
61-67 \\
70-81\end{array}$ & $\begin{array}{l}41 \\
46 \\
52 \\
58 \\
64 \\
75\end{array}$ & 90 & (c. \\
\hline 4 & $\begin{array}{l}\text { Universal Tent } \\
\text { (CO2 washout } \\
\text { off) } \\
\text { (Oxygenaire } \\
\text { Ltd.) }\end{array}$ & 3 & $\begin{array}{r}2 \\
4 \\
6 \\
8 \\
10 \\
20\end{array}$ & $\begin{array}{l}40-44 \\
42-46 \\
42-47 \\
42-47 \\
42-50 \\
44-52\end{array}$ & $\begin{array}{l}42 \\
43 \\
44 \\
44 \\
45 \\
47\end{array}$ & 65 & (d \\
\hline 5 & $\begin{array}{l}\text { Mark V Tent } \\
\text { (CO } \mathrm{CO}_{3} \text { washout } \\
\text { off) } \\
\text { (Oxygenaire } \\
\text { Ltd.) }\end{array}$ & 2 & $\begin{array}{r}2 \\
4 \\
6 \\
8 \\
10\end{array}$ & $\begin{array}{l}40-41 \\
41-44 \\
45-51 \\
50-52 \\
50-52\end{array}$ & $\begin{array}{l}40 \\
42 \\
48 \\
51 \\
51\end{array}$ & 70 & (e : \\
\hline 6 & $\begin{array}{l}\text { Venturi Head } \\
\text { Tent } \\
\text { (Oxygenaire } \\
\text { Ltd.) }\end{array}$ & 3 & $\begin{array}{l}2 \\
4 \\
6\end{array}$ & $\begin{array}{c}23 \cdot 5-24 \cdot 5 \\
26 \cdot 5-27 \cdot 5 \\
32-34\end{array}$ & $\begin{array}{l}24 \\
27 \\
33\end{array}$ & $\begin{array}{c}24 \cdot 5 \\
28 \\
32-34\end{array}$ & \\
\hline
\end{tabular}

Notes: (a), (d), and (e) Flushing at $101 . / \mathrm{min}$. for 30 minutes; thereafter readings after 20 minutes at given flow rate. (b) Readings after flushing at 10 and $201 . / \mathrm{min}$ after readings after 20 minutes at given flow rate.

Shields Universal Croupette), and 3 (Oxygenaire Humidaire Tent) are used for infants and young children, whereas Tents 4 (Oxygenaire Universal Tent) and 5 (Oxygenaire Mark V Tent) are more suitable for older children who may find the others too confined. A high humidity is provided by each except Tent 4,

\footnotetext{
- Department of Child Life and Health, University of Edinburgh, and
} the Royal Hospital for Sick Children, Edinburgh but coolness for fevered children is obtainable in all. Tent 6 (Oxygenaire Venturi Head Tent) is designed to provide controlled oxygen therapy to adults with chronic respiratory insufficiency, during exacerbations of infection.

The incubators (Table II) are used in the neonatal period and provide high humidity and accurate temperature control in addition to oxygen. The Air-Shields Intensive-Care Isolette and the Oxygenaire New Incubator are fitted with a device to limit oxygen concentration to $40 \%$ or less, though higher concentrations are possible when necessary. The Oxygenaire Series III Incubator is included in this study as it is still widely used. The Oxygenaire Mark III Portable Incubator is generally used to transport newborn infants from home to hospital, thereby minimizing the risk of hypothermia and/or hypoxia during the journey.

TABLB II.-Oxygen Concentrations in Incubators Under Ideal Clinical

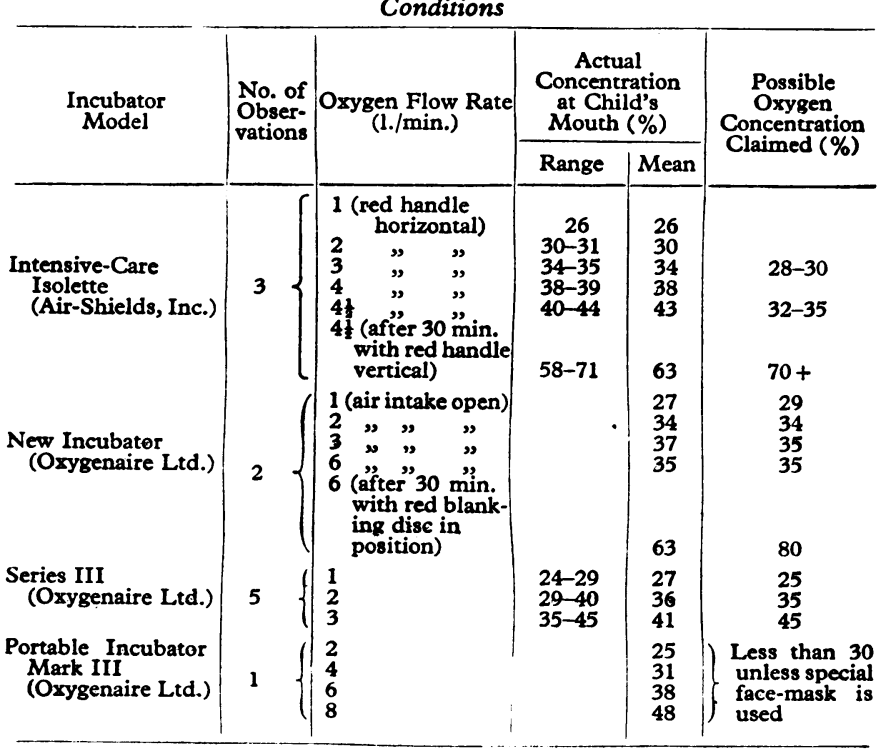

\section{Method}

The tents and incubators were tested under normal working conditions. In Tents 1 to 4 the patients were infants or young children believed on clinical grounds to require oxygen therapy, whereas healthy children co-operated in testing Tents 5 and 6. The canopies of Tents 1 to 5 were carefully tucked in to avoid leakage, and all zips were tightly closed. Each tent was then flushed as recommended (usually 10 litres of oxygen per minute for 30 minutes) and the oxygen flow rate subsequently adjusted to $2,4,6,8,10$, and $201 . / \mathrm{min}$. The oxygen flow meters used were supplied by the British Oxygen Company and are calis. brated from 0 to $10 \mathrm{l} . / \mathrm{min}$. A dual outlet regulator was used to provide flow rates of $201 . / \mathrm{min}$. Samples of inspired gas were taken from within 1 in. $(2.5 \mathrm{~cm}$.) of the child's mouth after 20 minutes at each flow rate into $100-\mathrm{ml}$. lubricated glass syringes via stiff rubber tubing introduced through a small aperture in each tent. In this way samples were obtained under ideal clinical conditions. Tent 6 did not require flushing, and was sampled at oxygen flow rates of 2,4 , and $61 . / \mathrm{min}$. 
Tents 1 to 4 were also sampled at random on numerous occasions. These tents were invariably flushed before initial usage, but routine reflushing after feeding or other interference was often omitted.

The incubators were tested during use without previous flushing, every precaution being taken to avoid leakage. The oxygen concentration of gas samples was determined by a

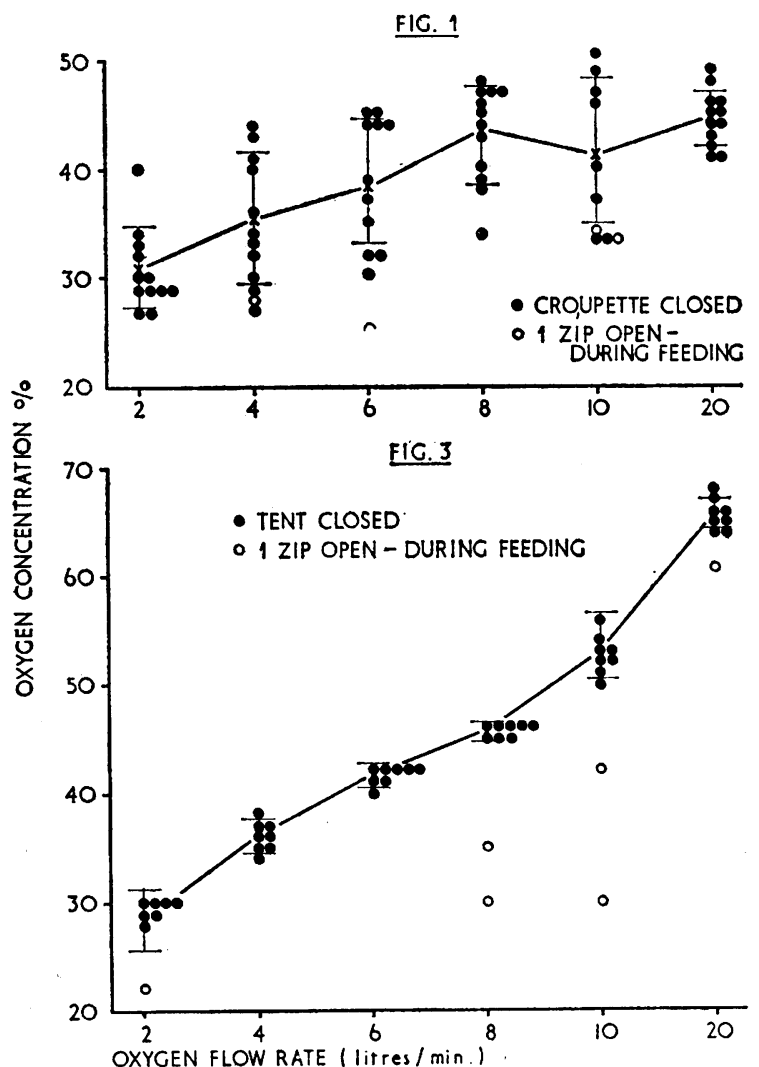

Tent 4 (Fig. 4). The mean oxygen concentrations, ideal and random, in Tents 1 to 4 at oxygen flow rates of $10 \mathrm{l} . / \mathrm{min}$. are shown in Fig. 5. Oxygen concentrations greater than $50 \%$ are invariably attained in Tent 3.

Table II shows the oxygen concentrations measured in incubators and relates them to their manufacturers' recommendations.

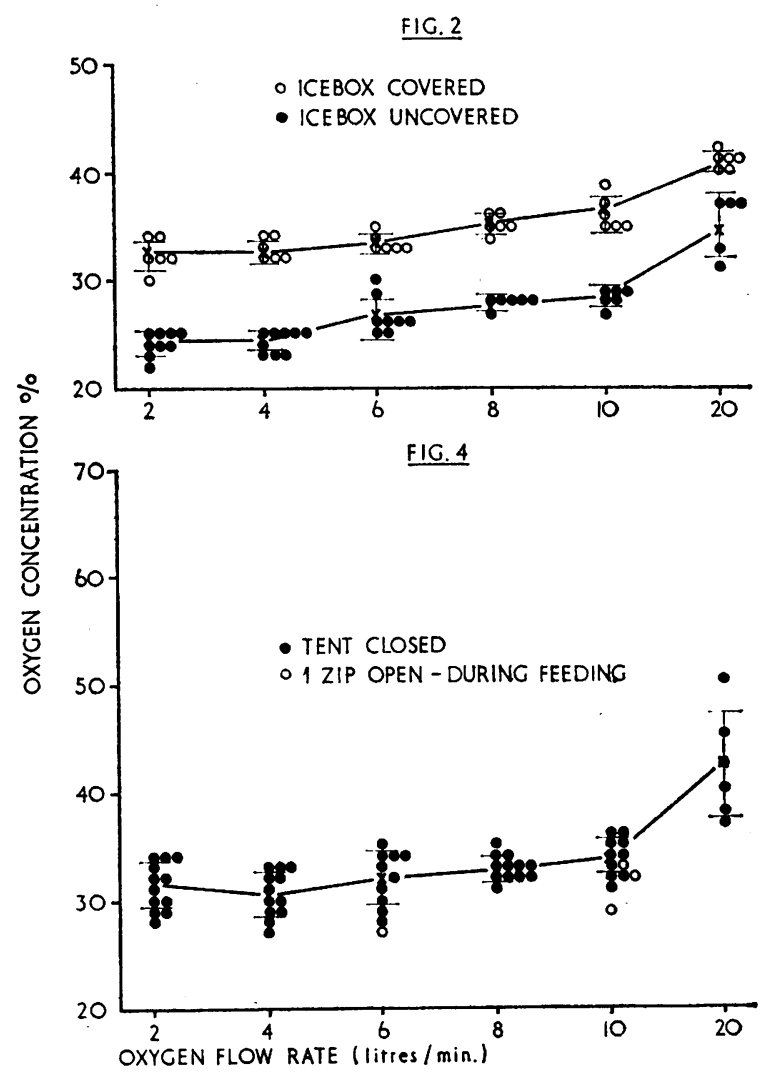

Fig. 1 - Concentration of oxygen ( \pm 1 S.D.) achieved in Air-Shields Type D Croupette in relation to flow rate of oxygen (random measurements). FIG. 2.-Concentration of oxygen ( \pm 1 S.D.) achieved in Air-Shields Universal Croupette in relation to flow rate of oxygen (random measurements). FIG. 3. - Concentration of oxygen ( \pm 1 S.D.) achieved in Oxygenaire Humidaire Tent in relation to flow rate of oxygen (random measurements). FIG. 4. - Concentration of oxygen ( \pm 1 S.D.) achieved in Oxygenaire Universal Tent in relation to flow rate of oxygen (random measurements).

D.C.L. 101 paramagnetic oxygen analyser calibrated with air and nitrogen (Nunn et al., 1964).

\section{Results}

The oxygen concentrations attained in tents under ideal clinical conditions are shown in Table I. An oxygen concentration exceeding $50 \%$ was attained in Tents $1,3,4$, and 5 at a flow rate of $101 . / \mathrm{min}$., whereas $31 \%$ was the highest concentration attained in Tent 2 at a similar flow rate. The oxygen concentrations in Tents 1,3, and 6 are close to those claimed possible by their manufacturers, while the levels in Tent 5 are similar to those published by Freedman (1964).

The results of random sampling (Tents 1 to 4 ) are shown in Figs. 1-4. When Tent 1 is used as recommended with the pressure gauge in the "green area" (usually $61 . / \mathrm{min}$.), oxygen concentrations of 30 to $45 \%$ are achieved (Fig. 1). Higher concentrations (by 4-6\%) are possible when the icebox is covered. Similarly, higher oxygen concentrations are attained in Tent 2 when the icebox is sealed over with polyethylene (Fig. 2). This improves contact between the outer and inner ice-tanks, where leaks may be associated with considerable air indrawing due to the Venturi circulation at that point. In Tent 3 an oxygen concentration of $40 \%$ is readily achieved at a flow rate of $61 . / \mathrm{min}$. (Fig. 3), whereas a flow rate of $20 \mathrm{l}$./min. is required to produce a similar concentration in

\section{Comment}

The oxygen requirements of hypoxic children may vary greatly, and depend on the cause and severity of the hypoxia. The principles underlying rational oxygen therapy have been reviewed (Brit. med. F., 1964), and Flenley (1967) has suggested that oxygen therapy should aim to provide a partial pressure of at least $10 \mathrm{~mm}$. of mercury at the cellular mitochondria.

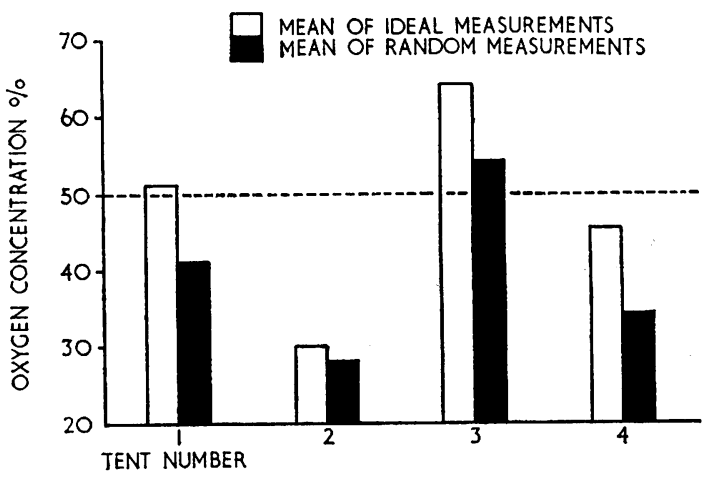

Fig. 5.-Oxygen concentrations in Tents 1 (Air-Shields Type D Croupette), 2 (Air-Shields Universal Croupette), 3 (Oxygenaire Humidaire Tent), and 4 (Oxygenaire Universal Tent) at axygen flow rate of $10 \mathrm{1}$. $/ \mathrm{min}$. Comparison of means of ideal and random measurements. 
It is probable that in many instances an oxygen concentration of 50 volumes \% -that is, the standard recommended for tents by the Committee on Public Health Relations of the New York Academy of Medicine (1950)-fulfils this condition. While this concentration of oxygen may be dangerous to premature babies, such babies are generally nursed in incubators in which special provision is made to regulate the ambient oxygen concentration to under $40 \%$ (Table II), thus minimizing the risk of retrolental fibroplasia. Furthermore, the use of high oxygen concentrations in the treatment of chronic hypoxic children with hypoventilation may produce carbon dioxide narcosis (Bruck, 1957). There is, however, little risk of precipitating respiratory depression by this means in infants with acute lower respiratory tract infections (Reynolds, 1963 ; Simpson and Flenley, 1967). The main use of oxygen tents and croupettes is probably in the treatment of such cases, in which an inspired oxygen concentration of $40 \%$ or more may be necessary to ensure a normal arterial oxygen tension $\left(\mathrm{PO}_{2}\right)$ (Simpson and Flenley, 1967). This requirement is most likely to be met in Tent 3 (Figs. 3 and 5), in which an oxygen concentration of $50 \%$ is attainable at a flow-rate of $101 . / \mathrm{min}$.

In chronic respiratory insufficiency in infancy and childhood the place of oxygen therapy has yet to be defined precisely, though the risks of injudicious oxygen therapy to children with cystic fibrosis of the pancreas are recognized (Bruck, 1957). There may also be a place for controlled oxygen therapy in the treatment of asthma (Schiller et al., 1951). In such instances Tent 6 may be of value, though a young child, apprehensive and fighting for breath, might find it too confined. The children who helped in testing this tent (aged 7-9 years) were fully at ease within a few minutes.

The indications for oxygen therapy in the newborn have been reviewed by Tizard (1964). Incubators are generally used in this period and are seldom appropriate for infants over 2-3 months of age. The recognition that retinal damage in premature babies is related more to a high arterial oxygen tension than the ambient oxygen concentration per se has resulted in improved incubator design. Newer models provide an ambient oxygen concentration of less than $40 \%$ at a flow rate of $31 . / \mathrm{min}$., but can be adjusted to supply $60-70 \%$ oxygen when necessary (Table II). This is of particular importance in the treatment of infants with venous-arterial shunts, as shunted blood does not perfuse the lung alveoli. Even so, the addition of oxygen to the blood which does undergo gas exchange in the lung may improve tissue oxygenation. The danger of pulmonary epithelial damage-the LorrainSmith (1899) effect-from the inhalation of high oxygen concentrations is probably of importance in humans (New Engl. $\mathcal{F}$. Med., 1967), and should be borne in mind whenever high concentrations of oxygen are used therapeutically for a prolonged period.

\section{Summary}

The oxygen concentrations attained in tents and incubators during routine paediatric use are reported. An oxygen concentration of $50-60 \%$ is most readily attained in the Oxygenaire Humidaire Tent-the most efficient of the tents tested. Accurately controlled oxygen therapy in the range of 24-34\% is attainable in the Venturi Head Tent, which may find a place in paediatric oxygen therapy. Incubators in neonatal use generally fulfil their manufacturers' specifications.

We wish to thank Professor J. O. Forfar, Dr. J. W. Farquhar, Dr. D. C. Flenley, and Dr. D. G. Barr for their advice and for helpful criticism of this paper. We are also grateful to Air-Shields (U.K.) Ltd. and Oxygenaire Ltd. for their helpful co-operation throughout this study.

Requests for reprints should be addressed to Dr. H. Simpson, Department of Child Life and Health, 17 Hatton Place, Edinburgh 9.

ADDENDUM.-Since this paper has been prepared the canopy of Tent 2 (Air-Shields Universal Croupette) has been modified slightly. As a result there is now no distortion of the oxygen inlets to the tent. This allows closer apposition of the outer and inner tanks of the icebox than had previously been possible. On retesting this Croupette with the "new" canopy, an oxygen concentration of $45 \%$ was obtained after one hour at a flow rate of $10 \mathrm{l} . / \mathrm{min}$., under ideal clinical conditions. The provision of a spring-loaded clip between the outer and inner tanks of the icebox in future models of this Croupette may further minimize the possibility of leakage.

\section{REFERENCES}

Batson, R., and Young, W. C. (1958). Pediatrics, 22, 436.

Brit. med. F., 1964, 2, 1580.

Bruck, E. (1957). Amer. f. Dis. Child., 94, 435.

Burgess, A. M., and Burgess, A. M., jun. (1932). New Engl. f. Med., $207,1078$.

Committee on Public Health Relations of the New York Academy of Medicine (1950). f. Amer. med. Ass., 144, 25.

Downes, J. J., and Striker, T. W. (1966). Acta anaesth. scand., Suppl. No. 23, p. 747.

Flenley, D. C. (1967). Lancet, 1, 270.

Freedman, B. J. (1964). Thorax, 19, 568.

Godfrey, R. (1959). Med. F. Aust., 2, 789.

Lorrain-Smith, J. (1899). F. Physiol. (Lond.), 24, 19.

Morrison, B. (1955). Lancet, 2, 752.

New Engl. F. Med., 1967, 276, 412.

Nunn, J. F., Bergman, N. A., Coleman, A. J., and Casselle, D. C. (1964). Brit. F. Anaesth., 36, 666

Reynolds, E. O. R. (1963). Brit. med. F., 1, 1192.

Schiller, I. W., Beale, H. D., Franklin, W., Lowell, F. C., and Halperin, M. H. (1951). f. Allergy, 22, 423.

Simpson, H., and Flenley, D. C. (1967). Lancet, 1, 7.

Tizard, J. P. M. (1964). Pediatrics, 34, 771. 